\title{
ESTUDOS FILOGENÉTICOS DA ORDEM CHARACIFORMES: TENDÊNCIAS E CARÊNCIAS
}

\section{PHYLOGENETIC STUDIES OF THE ORDER CHARACIFORMES: TRENDS AND LACKS}

\author{
Thaís Fernandes Mendonça Mota ${ }^{1}$, Sônia Maria Alves Pinto Prioli ${ }^{2}$, Alberto José Prioli ${ }^{3}$ \\ ${ }^{1}$ Programa de Pós-Graduação em Biologia Comparada (PGB), Universidade Estadual de \\ Maringá (UEM). Endereço: Rua José de Souza Leite, 1622 Jd. Laranjeiras, Paranavaí, \\ Paraná. E-mail: tfmm_0412@hotmail.com. Fone: (044) 3422-5362. \\ ${ }^{2}$ Núcleo de Pesquisas em Limnologia, Ictiologia e Aquicultura (Nupélia), Universidade \\ Estadual de Maringá (UEM). Departamento de Biotecnologia, Genética e Biologia Celular, \\ Universidade Estadual de Maringá (UEM). E-mail: priolis@nupelia.uem.br \\ ${ }^{3}$ Núcleo de Pesquisas em Limnologia, Ictiologia e Aquicultura (Nupélia), Universidade \\ Estadual de Maringá (UEM). Departamento de Biotecnologia, Genética e Biologia Celular, \\ Universidade Estadual de Maringá (UEM). E-mail: ajprioli@nupelia.uem.br
}

Data de recebimento: $18 / 03 / 2014$

Data da aprovação: 10/05/2014

\section{RESUMO}

Estima-se que o número de espécies existentes hoje é de aproximadamente de 3 a 5 milhões. Entre os peixes de água doce,a ordem Characiformes está entre as mais diversas, com aproximadamente 2.000 espécies. A classificação deste grupo vem sendo reavaliada e novos estudos devem ser feitos para estabelecer suas relações filogenéticas. Por meio de dados cienciométricos é possível identificar as tendências e o desenvolvimento do conhecimento, indicando quais abordagens devem ser conduzidas. Desta forma, o objetivo deste trabalho foi realizar um estudo cienciométrico para avaliar o desenvolvimento do conhecimento sobre a filogenia de Characiformes. O levantamento dos estudos foi realizado por meio do banco de dados publicados no sítio do Thomson Reuters Web of Knowledge. Alguns critérios foram utilizados para selecionar as publicações, totalizando 44 trabalhos. Durante o ano de 2013, 15,9\% dos trabalhos foram publicados; a maior parte foi em nível de gênero. O gênero Moenkhausia e as famílias Characidae e Alestidae foram os mais estudados. A grande maioria das reconstruções filogenéticas utilizou caracteres moleculares. Instituições brasileiras realizaram $43,1 \%$ dos trabalhos. Podemos concluir que a filogenia de Characiformes ainda não está bem resolvida, com apenas alguns táxons estudados e poucos trabalhos fizeram uma análise mais abrangente da ordem. Sugerimos novas pesquisas em táxons poucos estudados, sobretudo análises mais abrangentes e com dados moleculares e morfológicos.

Palavras-chave: Filogenia. Cienciometria. Peixes. Molecular. Morfologia.

\begin{abstract}
It is estimated that the number of species existing today is nearly 3 to 5 million. Among freshwater fish, the order Characiformes is among the most diverse, with nearly 2.000 species. The classification of this group has been re-evaluated and further studies should be made to establish their phylogenetic relationships. Through scientometric data is possible to identify trends and knowledge development, indicating which approaches
\end{abstract}


should be conducted. Thus, the aim of this study was to conduct a scientometric study to evaluate the development of knowledge about the phylogeny of Characiformes. The survey of the studies was conducted by the database published on the website of the Thomson Reuters Web of Knowledge. Some criteria were used to select publications; 44 papers were selected. During the year 2013, $15.9 \%$ of work were posted. Most of the work was at genus level. The Moenkhausia genus and the families Characidae and Alestidae were the most estudied. The vast majority of phylogenetic reconstructions used molecular characters. Brazilian institutions did $43.1 \%$ of work. We conclude that phylogeny of Characiformes is still not well solved, with only a few taxa studied and few studies have made a more comprehensive analysis of the order. We recommend further researches on understudied taxa, mainly analyzes broader and with molecular and morphological data.

Keywords: Phylogeny. Scientometrics. Fish. Molecular. Morphology.

\section{INTRODUÇÃO}

Existe uma alta diversidade de vida na Terra, estima-se que o número de espécies existentes hoje é de aproximadamente de 3 a 5 milhões (COSTELLO et al., 2013). A sistemática filogenética é uma ferramenta importante para entender esta diversidade à luz da evolução e para reconstruir a história evolutiva da vida (HENNIG, 1966). Segundo a metodologia filogenética, a classificação dos organismos deve refletir as relações de parentesco entre os táxons incluídos na classificação (AMORIM, 2002). Essas relações genealógicas são obtidas a partir de análises de homologias, que são características de origem comum em grupos geneticamente relacionados. A análise filogenética pode utilizar diferentes tipos de caracteres morfológicos, moleculares e etológicos (WHEELER et al., 2006).

A história evolutiva dos peixes da ordem Characiformes ainda é incerta. Os peixes dessa ordem estão entre os mais diversos e abundantes componentes de água doce do mundo, com aproximadamente 2.000 espécies distribuídas em 23 famílias; destas, quatro são africanas e 19, neotropicais (OLIVEIRA et al., 2011; ESCHMEYER; FONG, 2013). Os Characiformes apresentam uma variada especialização ecológica, evidenciada pela enorme variedade de formas, tamanhos e hábitos alimentares (GERY, 1977). Possuem notável importância ecológica, devido a sua abundância e diversidade (LOWE-MCCONNELL, 1999), além de muitos serem comercialmente importantes como alimentos e peixes ornamentais (WEITZMAN; PALMER, 2003).

A família Characidae é a maior da ordem e as inter-relações desse grupo permanecem confusas, com muitos gêneros considerados incertaesedis (LIMA et al., 2003). A classificação dos Characiformes vem sofrendo grandes modificações, com vários estudos recentes (CALCAGNOTTO et al., 2005; JAVONILLO et al., 2010; OLIVEIRA et al., 2011; DATOVO; CASTRO, 2012; MATTOX; TOLEDOPIZA, 2012). Contudo há necessidade de muitos outros para estabelecer as relações filogenéticas desse grupo (NELSON, 2006).

Com base no desenvolvimento do conhecimento científico, tornou-se necessária a avaliação de tais avanços. A quantificação da produção científica é um dos meios de avaliar o desenvolvimento científico de uma determinada área. A cienciometria pode ser definida como o estudo dos aspectos quantitativos da ciência (TAGUE-SUTCLIFFE, 1992). Por meio de dados cienciométricos é possível identificar as tendências e o desenvolvimento do conhecimento, indicando quais estudos devem ser realizados. Desta forma, é uma ferramenta interdisciplinar para auxiliar políticas para o desenvolvimento científico (SPINAK, 1998).

Como a filogenia dos Characiformes ainda não está bem resolvida, o objetivo deste trabalho foi realizar um estudo cienciométrico para avaliar o desenvolvimento do conhecimento sobre a filogenia de Characiformes.

\section{METODOLOGIA}

A busca por textos científicos foi realizada na base de dados ISI Web of Knowledge,devido a sua abrangência quanto ao número de publicações e qualidade das revistas indexadas. As palavras-chave utilizadas foram "Phylogeny and Characiformes", para selecionar os artigos com assuntos interligados. Não 
foi delimitando o período específico, pois foram contabilizados todos os trabalhos encontrados até dezembro de 2013. A quantidade de vezes que o artigo foi citado também está disponível nesse banco de dados. Foram selecionadas as publicações que apresentavam as seguintes informações: (I) Filogenia de algum táxon relacionado a Characiformes; (II) ano de publicação; (III) táxon estudado; (IV) marcadores utilizados; (V) autores; (VI) países onde estão filiados os autores; (VII) número de vezes que o artigo foi citado; (VIII) periódico em que o artigo foi publicado. Pela coleta dessas informações, foi elaborado um conjunto de dados.

\section{RESULTADOS E DISCUSSÃO}

A ordem Characiformes é um dos maiores grupos de peixes de água doce. As relações filogenéticas desse grupo ainda não foram bem estabelecidas, em parte devido a sua grande diversidade morfológica, pequena variação da morfologia externa de alguns grupos, e/ou evolução convergente comum (NELSON, 2006). Nos últimos anos, vários estudos foram feitos em grande parte das famílias de Characiformes. De acordo com os critérios utilizados, foram selecionados 44 trabalhos.

A primeira publicação é de 1987 e a mais recente foi publicada em dezembro de 2013 (Figura 1). Durante o ano de 2013, 15,9\% dos trabalhos foram publicados. $\mathrm{Na}$ última década, mais de trezentas espécies de Characiformes foram descritas, e a previsão é que este número aumente (OLIVEIRA et al., 2011). Desta forma, ainda existem várias questões a serem resolvidas, principalmente porque a filogenia de algumas famílias é problemática, como a posição da família Crenuchidae (MIRANDE, 2010; OLIVEIRA et al., 2011).

Figura 1- Número de artigos sobre filogenia de Characiformes e ano de publicação

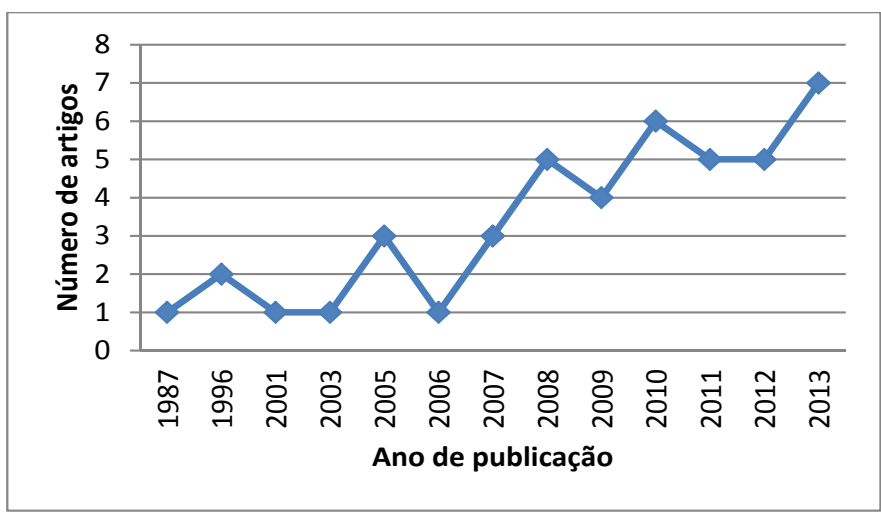

A maior parte dos trabalhos foi em nível de gênero, seguido de família, com $36,3 \%$ e $27,2 \%$, respectivamente; somente um artigo em nível de ordem (Figura 2). Entre os trabalhos que estudaram a filogenia de famílias, nove famílias foram incluídas nos estudos, e entre a filogenia de gênero, quinze gêneros foram analisados. As famílias mais estudadas foram: Characidae, em quatro trabalhos e Alestidae, em três. A filogenia do gênero Moenkhausia foi analisada em três trabalhos e dois artigos abordaram a do gênero Leporinus. Contudo, considerando as 23 famílias da ordem e os diversos gêneros, muitos grupos não foram devidamente explorados. Entre os 291 gêneros, setenta não foram estudados em qualquer dos trabalhos selecionados; entre esse, 26 são considerados incertaesedis (Tabela 1). Da mesma forma, a ordem carece de pesquisas mais amplas, já que existem alguns pontos conflitantes entre os diferentes estudos realizados.

Figura 2- Táxon estudado nos artigos sobre filogenia de Characiformes

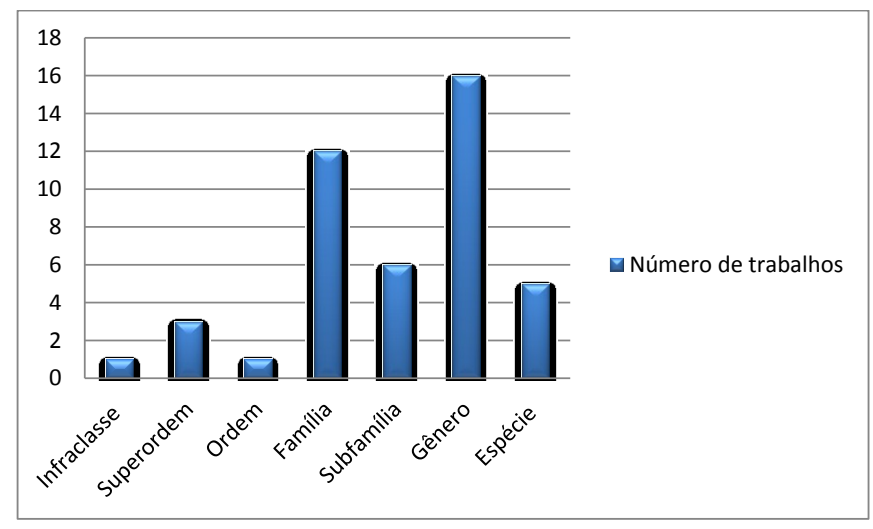


Tabela 1- Todas as famílias e gêneros estudados nos artigos selecionados e marcadores utilizados na reconstrução na filogenia. Em destaque, gêneros não estudados nas filogenias

\begin{tabular}{|c|c|c|c|}
\hline \multirow[t]{3}{*}{ GRUPO } & \multicolumn{3}{|c|}{ MARCADOR } \\
\hline & \multirow[t]{2}{*}{ Morfológico } & \multicolumn{2}{|l|}{ Molecular } \\
\hline & & Nuclear & Mitocondrial \\
\hline \multicolumn{4}{|l|}{ Acestrorhynchidae } \\
\hline Acestrorhynchus & Osteológicos & $\begin{array}{c}\text { RAG 1/RAG 2/MYH6/sh3px3/ S7/ TROP/ } \\
\mathrm{fkh/Sia}\end{array}$ & $\begin{array}{c}12 \mathrm{~s} \text { RNA / } 16 \mathrm{~s} \text { RNA/cyt-b/ COI/ } \\
\text { ATPase }\end{array}$ \\
\hline Gilbertolus & & RAG 1/RAG 2/MYH6 & 16 s RNA/ cyt-b \\
\hline Gnathocharax & & RAG 1/RAG 2/MYH6 & $\begin{array}{c}12 \text { s RNA /16 s RNA/ } \\
\text { cyt-b/ COI }\end{array}$ \\
\hline Heterocharax & Osteológicos & RAG 1/RAG 2/MYH6 & 16 s RNA/ cyt-b \\
\hline Hoplocharax & Osteológicos & RAG 1/RAG 2/MYH6 & $16 \mathrm{~s}$ RNA/ cyt-b \\
\hline Lonchogenys & Osteológicos & & \\
\hline Roestes & & RAG 1/RAG 2/MYH6 & 16 s RNA/ cyt-b \\
\hline \multicolumn{4}{|l|}{ Alestidae } \\
\hline Alestes & Osteológicos & $\begin{array}{c}\text { TROP/ fkh/ RAG 2/ Sia/ } \\
\text { RAG 1/ MYH6/sh3px3/ SEPY I/ AEPY } 6\end{array}$ & $\begin{array}{c}12 \mathrm{~s} \text { RNA/ } 16 \text { s RNA/ cyt-b/ } \\
\text { COI }\end{array}$ \\
\hline Alestopetersius & $\begin{array}{l}\text { Merísticos } \\
\text { Morfométricos } \\
\text { Osteológicos }\end{array}$ & $\begin{array}{l}\text { TROP/ fkh/ RAG 2/ Sia/ RAG1/ MYH6/ } \\
\text { sh3px3/ }\end{array}$ & $16 \mathrm{~s}$ RNA/cyt-b/COI \\
\hline Arnoldichthys & Osteológicos & TROP/ fkh/ RAG 2/ Sia/ MYH6/sh3px3 & 16 s RNA/cyt-b/ COI \\
\hline Bathyaethiops & Osteológicos & $\begin{array}{l}\text { TROP/ fkh/ RAG 2/ Sia/ } \\
\text { RAG 1/MYH6/ sh3px3 }\end{array}$ & 16 s RNA/ cyt-b/ COI \\
\hline Brachypetersius & Osteológicos & MYH6/sh3px3 & cyt-b/ COI \\
\hline Brycinus & Osteológicos & $\begin{array}{c}\text { TROP/ fkh/ RAG 2/ Sia/ } \\
\text { RAG 1/ MYH6/ RH/ EGR 1/ EGR 2B EGR3/ } \\
\text { sh3px3 }\end{array}$ & $\begin{array}{l}12 \text { s RNA/ } 16 \text { s RNA/ } \\
\text { cyt-b/ COI }\end{array}$ \\
\hline Bryconaethiops & Osteológicos & $\begin{array}{l}\text { TROP/ fkh/ RAG 2/ Sia/ } \\
\text { RAG } 1 / \text { MYH6/ sh3px3 }\end{array}$ & $\begin{array}{l}12 \text { s RNA/ } 16 \text { s RNA/ } \\
\text { cyt-b/ COI }\end{array}$ \\
\hline Bryconalestes & Osteológicos & MYH6/sh3px3 & cyt-b/ COI \\
\hline Chalceus & Osteológicos & $\begin{array}{c}\text { TROP/ fkh/ RAG 2/ Sia/ } \\
\text { RAG 1/ MYH6/ SEPY I/ AEPY } 6\end{array}$ & $\begin{array}{l}12 \text { s RNA/16 s RNA/ } \\
\text { cyt-b/ COI }\end{array}$ \\
\hline Clupeocharax & Osteológicos & MYH6/sh3px3 & cyt-b/ COI \\
\hline Hemigrammopetersius & Osteológicos & TROP/ fkh/ RAG 2/ Sia/ MYH6/sh3px3 & 16 s RNA/cyt-b/ COI \\
\hline Hydrocynus & Osteológicos & $\begin{array}{l}\text { TROP/ fkh/ RAG 2/ Sia/ } \\
\text { RAG 1/ MYH6/sh3px3 }\end{array}$ & 16 s RNA/ cyt-b/ COI \\
\hline Ladigesia & Osteológicos & $\begin{array}{l}\text { TROP/ fkh/ RAG 2/ Sia/ } \\
\text { RAG 1/ MYH6/ sh3px3 }\end{array}$ & 16 s RNA/ cyt-b/ COI \\
\hline Lepidarchus & Osteológicos & MYH6/sh3px3 & cyt-b/ COI \\
\hline Micralestes & Osteológicos & $\begin{array}{l}\text { TROP/ fkh/ RAG 2/ Sia/ } \\
\text { RAG 1/ MYH6/ sh3px3 }\end{array}$ & $\begin{array}{l}12 \text { s RNA/ } 16 \text { s RNA/ } \\
\text { cyt-b/COI }\end{array}$ \\
\hline Nannopetersius & Osteológicos & TROP/ fkh/ RAG 2/ Sia/ MYH6/sh3px3 & 16 s RNA/cyt-b/ COI \\
\hline Petersius & Osteológicos & & \\
\hline Phenacogrammus & Osteológicos & $\begin{array}{c}\text { TROP/ fkh/ RAG 2/ Sia/ } \\
\text { RAG 1/ MYH6/ RH/ EGR 1/ EGR 2B EGR3/ } \\
\text { sh3px3/ SEPY I/ AEPY 6 }\end{array}$ & $\begin{array}{l}16 \text { s RNA/ cyt-b/COI/ Genoma } \\
\text { mitocondrial }\end{array}$ \\
\hline Rhabdalestes & Osteológicos & TROP/ fkh/ RAG 2/ Sia/ MYH6/sh3px3 & $\begin{array}{l}12 \text { s RNA/ } 16 \text { s RNA/ } \\
\text { cyt-b/ COI }\end{array}$ \\
\hline Tricuspidalestes & Osteológicos & MYH6/sh3px3 & cyt-b/ COI \\
\hline Virilia & Osteológicos & & \\
\hline Anostomidae & & & \\
\hline
\end{tabular}


continuação

\begin{tabular}{|c|c|c|c|}
\hline GRUPO & \multicolumn{3}{|c|}{ MARCADOR } \\
\hline Abramites & & & $\begin{array}{l}12 \text { s RNA } / 16 \text { s RNA/ } \\
\text { D-loop }\end{array}$ \\
\hline \multicolumn{4}{|l|}{ Anostomoides } \\
\hline Anostomus & & RAG 1/RAG 2/MYH6 & $16 \mathrm{~s}$ RNA/ cyt-b \\
\hline Arrhinolemur & Osteológicos & & \\
\hline \multicolumn{4}{|l|}{ Gnathodolus } \\
\hline \multicolumn{4}{|l|}{ Laemolyta } \\
\hline \multicolumn{4}{|l|}{ Leporellus } \\
\hline Leporinus & $\begin{array}{l}\text { Osteológicos } \\
\text { Catiotípicos }\end{array}$ & RAG 1/RAG 2/MYH6/ SEPY I/ AEPY 6 & $\begin{array}{l}12 \text { s RNA / D-loop /16 s RNA/ } \\
\text { cyt-b }\end{array}$ \\
\hline Pseudanos & Osteológicos & & \\
\hline \multicolumn{4}{|l|}{ Rhytiodus } \\
\hline \multicolumn{4}{|l|}{ Sartor } \\
\hline Schizodon & & $\begin{array}{c}\text { RAG 1/ RAG 2/MYH6/RH/ EGR 1/ EGR 2B } \\
\text { EGR3 }\end{array}$ & $16 \mathrm{~s}$ RNA/ cyt-b \\
\hline \multicolumn{4}{|l|}{ Synaptolaemus } \\
\hline \multicolumn{4}{|l|}{ Hypomasticus } \\
\hline \multicolumn{4}{|l|}{ Petulanos } \\
\hline \multicolumn{4}{|l|}{ Bryconidae } \\
\hline Brycon & Osteológicos & $\begin{array}{l}\text { TROP/ fkh/ RAG 2/ Sia/ } \\
\text { RAG 1/ MYH6/ sh3px3 }\end{array}$ & $\begin{array}{l}12 \text { s RNA / } 16 \text { s RNA/ } \\
\text { cyt-b/ COI }\end{array}$ \\
\hline Chilobrycon & Osteológicos & & \\
\hline Henochilus & & RAG 1/RAG 2/MYH6 & 16 s RNA/ cyt-b \\
\hline Salminus & Osteológicos & $\begin{array}{l}\text { TROP/ fkh/ RAG 2/ Sia/ } \\
\text { RAG 1/ MYH6 }\end{array}$ & $\begin{array}{l}12 \text { s RNA / } 16 \text { s RNA/ } \\
\text { cyt-b/ COI }\end{array}$ \\
\hline \multicolumn{4}{|l|}{ Chalceidae } \\
\hline Chalceus & & $\begin{array}{c}\text { RAG 1/RAG 2/MYH6/ RH/ EGR 1/ EGR 2B } \\
\text { EGR3/sh3px3 }\end{array}$ & $\begin{array}{c}16 \text { s RNA/ cyt-b/ COI/ Genoma } \\
\text { mitocondrial }\end{array}$ \\
\hline \multicolumn{4}{|l|}{ Characidae } \\
\hline \multicolumn{4}{|l|}{ Acanthocharax } \\
\hline Acestrocephalus & Osteológicos & RAG 1/RAG 2/MYH6 & $16 \mathrm{~s} \mathrm{RNA} /$ cyt-b \\
\hline Acinocheirodon & Glandulares & RAG 1/RAG 2/MYH6 & $16 \mathrm{~s}$ RNA/ cyt-b \\
\hline Acrobrycon & Osteológicos & & \\
\hline Amazonspinther & & RAG 1/RAG 2/MYH6 & 16 s RNA/ cyt-b \\
\hline Aphyocharacidium & Osteológicos & RAG 1/RAG 2/MYH6 & $16 \mathrm{~s}$ RNA/ cyt-b \\
\hline Aphyocharax & Osteológicos & RAG 1/RAG 2/MYH6/ Sai/ TROP & $\begin{array}{l}12 \text { s RNA / } 16 \text { s RNA/ cyt-b/ } \\
\text { COI/ ND2 }\end{array}$ \\
\hline Aphyocheirodon & Glandulares & $\begin{array}{l}\text { TROP/ fkh/ RAG 2/ Sia/ } \\
\text { RAG 1/ MYH6 }\end{array}$ & 16 s RNA/ cyt-b \\
\hline Aphyodite & Osteológicos & RAG 1/RAG 2/MYH6 & $16 \mathrm{~s} \mathrm{RNA} /$ cyt-b \\
\hline \multicolumn{4}{|l|}{ Argopleura } \\
\hline Astyanacinus & & $\begin{array}{c}\text { TROP/ fkh/ RAG } 2 / \mathrm{Sia} / \\
\text { RAG } 1 / \text { MYH6 }\end{array}$ & $\begin{array}{l}12 \text { s RNA /16 s RNA/ } \\
\text { cyt-b/ COI }\end{array}$ \\
\hline Astyanax & $\begin{array}{l}\text { Espermáticos } \\
\text { Osteológicos }\end{array}$ & $\begin{array}{c}\text { RAG 1/RAG 2/MYH6/ } \\
\text { RH/ EGR 1/ EGR 2B EGR3/ TROP/ fkh/ Sia }\end{array}$ & $\begin{array}{l}12 \text { s RNA /16 s RNA/ } \\
\text { cyt-b/ } 12 \text { s RNA/ COI }\end{array}$ \\
\hline Atopomesus & & & \\
\hline
\end{tabular}


continuação

\begin{tabular}{|c|c|c|c|}
\hline GRUPO & \multicolumn{3}{|c|}{ MARCADOR } \\
\hline Attonitus & Osteológicos & & \\
\hline Aulixidens & Osteológicos & & \\
\hline Axelrodia & Osteológicos & & \\
\hline Bario & Osteológicos & RAG 1/RAG 2/MYH6 & 16 s RNA/ cyt-b \\
\hline Boehlkea & Espermáticos & & \\
\hline Brachychalcinus & Cariotípicos & RAG 1/RAG 2/MYH6 & 16 s RNA/ cyt-b \\
\hline Bramocharax & Osteológicos & RAG 1/RAG 2/MYH6 & $16 \mathrm{~s}$ RNA/ cyt-b \\
\hline Brittanichthys & & RAG 2/ 12 s RNA / 16 s RNA COI & \\
\hline \multicolumn{4}{|l|}{ Bryconacidnus } \\
\hline Bryconadenos & & RAG 1/RAG 2/MYH6 & $\begin{array}{c}12 \text { s RNA / } 16 \text { s RNA/ } \\
\text { cyt-b/ COI }\end{array}$ \\
\hline Bryconamericus & $\begin{array}{l}\text { Espermáticos } \\
\text { Osteológicos }\end{array}$ & $\begin{array}{c}\text { TROP/ fkh/ RAG 2/ Sia/ } \\
\text { RAG 1/ MYH6 }\end{array}$ & $\begin{array}{l}12 \text { s RNA / } 16 \text { s RNA/ } \\
\text { cyt-b/ COI }\end{array}$ \\
\hline Bryconella & & RAG 1/RAG 2/MYH6 & $16 \mathrm{~s}$ RNA/ cyt-b \\
\hline Bryconexodon & Osteológicos & & \\
\hline \multicolumn{4}{|l|}{ Caiapobrycon } \\
\hline Carlana & Osteológicos & RAG 1/RAG 2/MYH6 & $16 \mathrm{~s}$ RNA/ cyt-b \\
\hline Ceratobranchia & Espermáticos & RAG 1/RAG 2/MYH6 & $16 \mathrm{~s}$ RNA/ cyt-b \\
\hline Charax & Osteológicos & RAG 1/RAG 2/MYH6 & $16 \mathrm{~s}$ RNA/ cyt-b \\
\hline Cheirodon & $\begin{array}{l}\text { Glandulares } \\
\text { Osteológicos }\end{array}$ & $\begin{array}{c}\text { TROP/ fkh/ RAG 2/ Sia/ } \\
\text { RAG 1/ MYH6 }\end{array}$ & $\begin{array}{c}12 \text { s RNA /16 s RNA/ } \\
\text { cyt-b/ COI }\end{array}$ \\
\hline Cheirodontops & Glandulares & TROP/ fkh/ RAG 2/ Sia & 16 s RNA/ cyt-b \\
\hline Chrysobrycon & Osteológicos & & \\
\hline Compsura & Glandulares & RAG 1/RAG 2/MYH6 & $\begin{array}{c}12 \text { s RNA / } 16 \text { s RNA/ } \\
\text { cyt-b/ COI }\end{array}$ \\
\hline Coptobrycon & Osteológicos & RAG 1/RAG 2/MYH6 & 16 s RNA/ cyt-b \\
\hline Corynopoma & & RAG 1/RAG 2/MYH6 & $\begin{array}{c}12 \text { s RNA / } 16 \text { s RNA/ } \\
\text { cyt-b/ COI }\end{array}$ \\
\hline Creagrutus & $\begin{array}{l}\text { Espermáticos } \\
\text { Osteológicos }\end{array}$ & $\begin{array}{c}\text { TROP/ fkh/ RAG 2/ Sia/ } \\
\text { RAG 1/ MYH6 }\end{array}$ & $\begin{array}{c}12 \text { s RNA/16 s RNA/ } \\
\text { cyt-b/ COI }\end{array}$ \\
\hline Ctenobrycon & Osteológicos & RAG 1/RAG 2/MYH6 & $\begin{array}{c}12 \text { s RNA /16 s RNA/ } \\
\text { cyt-b/ COI }\end{array}$ \\
\hline Ctenocheirodon & & RAG 1/RAG 2/MYH6 & 16 s RNA/ cyt-b \\
\hline Cyanocharax & $\begin{array}{l}\text { Espermáticos } \\
\text { Osteológicos } \\
\end{array}$ & RAG 1/RAG 2/MYH6 & $\begin{array}{c}12 \text { s RNA / } 16 \text { s RNA/ } \\
\text { cyt-b/ COI }\end{array}$ \\
\hline \multicolumn{4}{|l|}{ Cyanogaster } \\
\hline Cynopotamus & Osteológicos & RAG 1/RAG 2/MYH6 & $\begin{array}{c}12 \text { s RNA / } 16 \text { s RNA/ } \\
\text { cyt-b/ COI }\end{array}$ \\
\hline \multicolumn{4}{|l|}{ Dectobrycon } \\
\hline Deuterodon & Osteológicos & RAG 1/RAG 2/MYH6 & 16 s RNA/ cyt-b \\
\hline Diapoma & Osteológicos & RAG 2 & $12 \mathrm{~s}$ RNA / $16 \mathrm{~s}$ RNA/ COI \\
\hline \multicolumn{4}{|l|}{ Ectrepopterus } \\
\hline \multicolumn{4}{|l|}{ Erythrocharax } \\
\hline Exodon & Osteológicos & $\begin{array}{c}\text { TROP/ fkh/ RAG 2/ Sia/ } \\
\text { RAG 1/ MYH6 }\end{array}$ & $\begin{array}{c}12 \text { s RNA/16 s RNA/ } \\
\text { cyt-b/ COI }\end{array}$ \\
\hline Galeocharax & Osteológicos & RAG 1/RAG 2/MYH6 & $\begin{array}{c}12 \text { s RNA /16 s RNA/ } \\
\text { cyt-b/ COI }\end{array}$ \\
\hline
\end{tabular}


continuação

\begin{tabular}{|c|c|c|c|}
\hline GRUPO & \multicolumn{3}{|c|}{ MARCADOR } \\
\hline \multicolumn{4}{|l|}{ Genycharax } \\
\hline Gephyrocharax & Osteológicos & $\begin{array}{c}\text { TROP/ fkh/ RAG 2/ Sia/ } \\
\text { RAG 1/ MYH6/ S7 }\end{array}$ & $\begin{array}{l}12 \mathrm{~s} \text { RNA / } 16 \text { s RNA/ } \\
\text { cyt-b/ COI/ ATPase }\end{array}$ \\
\hline Glandulocauda & Osteológicos & RAG 1/RAG 2/MYH6 & 16 s RNA/ cyt-b \\
\hline Grundulus & Osteológicos & & \\
\hline Gymnocharacinus & Osteológicos & & \\
\hline Gymnocorymbus & Osteológicos & RAG 1/RAG 2/MYH6/ SEPY I/ AEPY 6 & $\begin{array}{c}12 \text { s RNA / } 16 \text { s RNA/ } \\
\text { cyt-b/ COI }\end{array}$ \\
\hline \multicolumn{4}{|l|}{ Gymnotichthys } \\
\hline Hasemania & Osteológicos & RAG 1/RAG 2/MYH6 & $\begin{array}{c}12 \text { s RNA/16 s RNA/ } \\
\text { cyt-b/ COI }\end{array}$ \\
\hline Hemibrycon & $\begin{array}{l}\text { Espermáticos } \\
\text { Osteológicos }\end{array}$ & RAG 1/RAG 2/MYH6 & $\begin{array}{l}12 \text { s RNA/16 s RNA/ } \\
\text { cyt-b/ COI }\end{array}$ \\
\hline Hemigrammus & $\begin{array}{l}\text { Espermáticos } \\
\text { Osteológicos }\end{array}$ & $\begin{array}{l}\text { TROP/ fkh/ RAG 2/ Sia/ } \\
\text { RAG 1/ MYH6/ sh3px3 }\end{array}$ & $\begin{array}{l}12 \text { s RNA /16 s RNA/ } \\
\text { cyt-b/ COI }\end{array}$ \\
\hline Heterocheirodon & Glandulares & RAG 1/RAG 2/MYH6 & 16 s RNA/ cyt-b \\
\hline Hollandichthys & Osteológicos & RAG 1/RAG 2/MYH6/Sia/ Trop & $\begin{array}{c}16 \text { s RNA/ cyt-b/ COI/ND2/ } 12 \\
\text { s RNA }\end{array}$ \\
\hline Hyphessobrycon & $\begin{array}{l}\text { Espermáticos } \\
\text { Osteológicos } \\
\text { Morfométricos }\end{array}$ & $\begin{array}{l}\text { TROP/ fkh/ RAG 2/ Sia/ } \\
\text { RAG 1/ MYH6 }\end{array}$ & $\begin{array}{c}16 \text { s RNA/ cyt-b/ COI/ND2/ } 12 \\
\text { s RNA }\end{array}$ \\
\hline Hypobrycon & & RAG 1/RAG 2/MYH6 & $\begin{array}{c}12 \text { s RNA /16 s RNA/ } \\
\text { cyt-b/ COI }\end{array}$ \\
\hline \multicolumn{4}{|l|}{ Hysteronotus } \\
\hline Inpaichthys & Osteológicos & $\begin{array}{l}\text { TROP/ fkh/ RAG 2/ Sia/ } \\
\text { RAG 1/ MYH6 }\end{array}$ & $\begin{array}{c}12 \mathrm{~s} \text { RNA / } 16 \text { s RNA/ } \\
\text { cyt-b/ COI }\end{array}$ \\
\hline \multicolumn{4}{|l|}{ Iotabrycon } \\
\hline Jupiaba & Osteológicos & RAG 1/RAG 2/MYH6 & $\begin{array}{c}12 \text { s RNA / } 16 \text { s RNA/ } \\
\text { cyt-b/ COI }\end{array}$ \\
\hline Knodus & $\begin{array}{l}\text { Espermáticos } \\
\text { Osteológicos }\end{array}$ & $\begin{array}{c}\text { TROP/ fkh/ RAG 2/ Sia/ } \\
\text { RAG 1/ MYH6 }\end{array}$ & $\begin{array}{l}12 \text { s RNA / } 16 \text { s RNA/ } \\
\text { cyt-b/ COI }\end{array}$ \\
\hline Kolpotocheirodon & Glandulares & RAG 1/RAG 2/MYH6 & 16 s RNA/ cyt-b \\
\hline \multicolumn{4}{|l|}{ Landonia } \\
\hline Lepidocharax & $\begin{array}{l}\text { Osteológicos } \\
\text { Histológicos }\end{array}$ & & \\
\hline Leptagoniates & Osteológicos & RAG 1/RAG 2/MYH6 & 16 s RNA/ cyt-b \\
\hline \multicolumn{4}{|l|}{ Leptobrycon } \\
\hline Lophiobrycon & & RAG 1/RAG 2/MYH6/ Sai/TROP & 16 s RNA/ cyt-b/ COI/ND2 \\
\hline Macropsobrycon & & RAG 1/RAG 2/MYH6 & $\begin{array}{c}12 \text { s RNA /16 s RNA/ } \\
\text { cyt-b/ COI }\end{array}$ \\
\hline Markiana & Osteológicos & RAG 1/RAG 2/MYH6 & 16 s RNA/ cyt-b \\
\hline \multicolumn{4}{|l|}{ Megalamphodus } \\
\hline \multicolumn{4}{|l|}{ Microgenys } \\
\hline Microschemobrycon & Osteológicos & RAG 1/RAG 2/MYH6 & 16 s RNA/ cyt-b \\
\hline Mimagoniates & Osteológicos & $\begin{array}{c}\text { TROP/ fkh/ RAG 2/ Sia/ } \\
\text { RAG 1/ MYH6 }\end{array}$ & $\begin{array}{c}16 \text { s RNA/ cyt-b/ COI/ND2/ } 12 \\
\text { s RNA }\end{array}$ \\
\hline \multicolumn{4}{|l|}{ Mixobrycon } \\
\hline Moenkhausia & Espermáticos Osteológicos & TROP/ fkh/ RAG 2/ Sia RAG 1/ MYH6 & $\begin{array}{c}12 \text { s RNA /16 s RNA/ } \\
\text { cyt-b/ COI }\end{array}$ \\
\hline Monotocheirodon & & & \\
\hline
\end{tabular}


continuação

\begin{tabular}{|c|c|c|c|}
\hline GRUPO & \multicolumn{3}{|c|}{ MARCADOR } \\
\hline Myxiops & & RAG 1/RAG 2/MYH6 & 16 s RNA/ cyt-b \\
\hline Nanocheirodon & Glandulares & RAG 1/RAG 2/MYH6 & 16 s RNA/ cyt-b \\
\hline Nantis & Osteológicos & & \\
\hline Nematobrycon & Osteológicos & RAG 1/RAG 2/MYH6 & $\begin{array}{c}12 \text { s RNA /16 s RNA/ } \\
\text { cyt-b/ COI }\end{array}$ \\
\hline Nematocharax & & RAG 1/RAG 2/MYH6/Sia/Trop & $16 \mathrm{~s}$ RNA/ cyt-b/ COI/ND2 \\
\hline Odontostilbe & $\begin{array}{l}\text { Glandulares } \\
\text { Osteológicos }\end{array}$ & RAG 1/RAG 2/MYH6 & $\begin{array}{c}12 \text { s RNA /16 s RNA/ } \\
\text { cyt-b/ COI }\end{array}$ \\
\hline Odontostoechus & $\begin{array}{l}\text { Espermáticos } \\
\text { Osteológicos } \\
\end{array}$ & RAG 1/RAG 2/MYH6 & $\begin{array}{c}12 \text { s RNA / } 16 \text { s RNA/ } \\
\text { cyt-b/ COI }\end{array}$ \\
\hline \multicolumn{4}{|l|}{ Oligobrycon } \\
\hline Oligosarcus & Osteológicos & RAG 1/RAG 2/MYH6 & $\begin{array}{c}12 \text { s RNA / } 16 \text { s RNA/ } \\
\text { cyt-b/ COI }\end{array}$ \\
\hline Orthospinus & & RAG 1/RAG 2/MYH6 & 16 s RNA/ cyt-b \\
\hline \multicolumn{4}{|l|}{ Othonocheirodus } \\
\hline \multicolumn{4}{|l|}{ Oxybrycon } \\
\hline Paracheirodon & Osteológicos & RAG 1/RAG 2/MYH6/ SEPY I/ AEPY 6 & $\begin{array}{l}12 \text { s RNA /16 s RNA/ } \\
\text { cyt-b/ COI }\end{array}$ \\
\hline Paragoniates & Osteológicos & RAG 1/RAG 2/MYH6 & 16 s RNA/ cyt-b \\
\hline Parapristella & Osteológicos & & \\
\hline \multicolumn{4}{|l|}{ Parastremma } \\
\hline Parecbasis & Osteológicos & RAG 1/RAG 2/MYH6 & 16 s RNA/ cyt-b \\
\hline \multicolumn{4}{|l|}{ Petitella } \\
\hline \multicolumn{4}{|l|}{ Phallobrycon } \\
\hline \multicolumn{4}{|l|}{ Phenacobrycon } \\
\hline Phenacogaster & Osteológicos & RAG 1/RAG 2/MYH6 & $\begin{array}{c}12 \text { s RNA /16 s RNA/ } \\
\text { cyt-b/ COI }\end{array}$ \\
\hline Phenagoniates & Osteológicos & RAG 1/RAG 2/MYH6 & 16 s RNA/ cyt-b \\
\hline Piabarchus & & RAG 1/RAG 2/MYH6 & 16 s RNA/ cyt-b \\
\hline Piabina & $\begin{array}{l}\text { Espermáticos } \\
\text { Osteológicos }\end{array}$ & RAG 1/RAG 2/MYH6 & $\begin{array}{c}12 \mathrm{~s} \mathrm{RNA} / 16 \mathrm{~s} \mathrm{RNA} / \\
\text { cyt-b/ COI }\end{array}$ \\
\hline Planaltina & Osteológicos & RAG 1/RAG 2/MYH6 & 16 s RNA/ cyt-b \\
\hline Poptella & Osteológicos & RAG 1/RAG 2/MYH6 & $\begin{array}{c}12 \mathrm{~s} \mathrm{RNA} / 16 \mathrm{~s} \mathrm{RNA} / \\
\text { cyt-b/ COI }\end{array}$ \\
\hline \multicolumn{4}{|l|}{ Priocharax } \\
\hline Prionobrama & Osteológicos & RAG 1/RAG 2/MYH6 & 16 s RNA/ cyt-b \\
\hline Pristella & Osteológicos & RAG 1/RAG 2/MYH6 & 16 s RNA/ cyt-b \\
\hline Probolodus & Osteológicos & RAG 1/RAG 2/MYH6 & 16 s RNA/ cyt-b \\
\hline Prodontocharax & $\begin{array}{l}\text { Glandulares } \\
\text { Osteológicos } \\
\end{array}$ & $\begin{array}{c}\text { TROP/ fkh/ RAG 2/ Sia/ } \\
\text { RAG 1/ MYH6 }\end{array}$ & $\begin{array}{c}12 \text { s RNA /16 s RNA/ } \\
\text { cyt-b/ COI }\end{array}$ \\
\hline Psellogrammus & Osteológicos & RAG 1/RAG 2/MYH6 & 16 s RNA/ cyt-b \\
\hline Pseudochalceus & Osteológicos & $\mathrm{Sia} / \mathrm{TROP}$ & 16 s RNA/ COI/ND2/ \\
\hline Pseudocheirodon & & RAG 1/RAG 2/MYH6 & 16 s RNA/ cyt-b \\
\hline Pseudocorynopoma & Osteológicos & RAG 1/RAG 2/MYH6 & $\begin{array}{c}12 \mathrm{~s} \mathrm{RNA} / 16 \mathrm{~s} \text { RNA/ } \\
\text { cyt-b/ COI }\end{array}$ \\
\hline \multicolumn{4}{|l|}{ Pterobrycon } \\
\hline Ptychocharax & & & \\
\hline
\end{tabular}


continuação

\begin{tabular}{|c|c|c|c|}
\hline GRUPO & \multicolumn{3}{|c|}{ MARCADOR } \\
\hline Rachoviscus & Osteológicos & RAG 1/RAG 2/MYH6/ Sia/ TROP & $\begin{array}{l}16 \text { s RNA/ cyt-b/ COI/ND2/ } 12 \\
\text { s RNA }\end{array}$ \\
\hline Rhinobrycon & $\begin{array}{l}\text { Espermáticos } \\
\text { Osteológicos } \\
\end{array}$ & & \\
\hline \multicolumn{4}{|l|}{ Rhinopetitia } \\
\hline Rhoadsia & Osteológicos & & \\
\hline Roeboexodon & Osteológicos & RAG 1/RAG 2/MYH6 & 16 s RNA/ cyt-b \\
\hline Roeboides & Osteológicos & $\begin{array}{l}\text { TROP/ fkh/ RAG 2/ Sia/ } \\
\text { RAG 1/ MYH6/ S7 }\end{array}$ & $\begin{array}{l}12 \mathrm{~s} \text { RNA /16 s RNA/ } \\
\text { cyt-b/ COI/ ATPase }\end{array}$ \\
\hline Saccoderma & Glandulares & RAG 1/RAG 2/MYH6 & 16 s RNA/ cyt-b \\
\hline \multicolumn{4}{|l|}{ Schultzites } \\
\hline \multicolumn{4}{|l|}{ Scissor } \\
\hline \multicolumn{4}{|l|}{ Scopaeocharax } \\
\hline \multicolumn{4}{|l|}{ Serrabrycon } \\
\hline Serrapinnus & $\begin{array}{l}\text { Glandulares } \\
\text { Osteológicos }\end{array}$ & RAG 1/RAG 2/MYH6 & $\begin{array}{l}12 \text { s RNA } / 16 \text { s RNA/ } \\
\text { cyt-b/ COI }\end{array}$ \\
\hline Spintherobolus & Osteológicos & RAG 1/RAG 2/MYH6 & 16 s RNA/ cyt-b \\
\hline Stethaprion & Osteológicos & RAG 1/RAG 2/MYH6 & 16 s RNA/ cyt-b \\
\hline Stichonodon & Osteológicos & & \\
\hline Stygichthys & & RAG 1/RAG 2/MYH6 & $16 \mathrm{~s}$ RNA/ cyt-b \\
\hline Tetragonopterus & Osteológicos & RAG 1/RAG 2/MYH6 & $\begin{array}{l}12 \text { s RNA /16 s RNA/ } \\
\text { cyt-b/ COI }\end{array}$ \\
\hline Thayeria & $\begin{array}{l}\text { Espermáticos } \\
\text { Osteológicos }\end{array}$ & RAG 1/RAG 2/MYH6 & $\begin{array}{l}12 \text { s RNA/16 s RNA/ } \\
\text { cyt-b/ COI }\end{array}$ \\
\hline \multicolumn{4}{|l|}{ Thrissobrycon } \\
\hline \multicolumn{4}{|l|}{ Trochilocharax } \\
\hline \multicolumn{4}{|l|}{ Tucanoichthys } \\
\hline \multicolumn{4}{|l|}{ Tyttobrycon } \\
\hline Tyttocharax & & RAG 1/RAG 2/MYH6 & $16 \mathrm{~s}$ RNA/ cyt-b \\
\hline Xenagoniates & Osteológicos & RAG 1/RAG 2/MYH6 & $16 \mathrm{~s} \mathrm{RNA} /$ cyt-b \\
\hline Xenurobrycon & & RAG 1/RAG 2/MYH6 & $16 \mathrm{~s} \mathrm{RNA} /$ cyt-b \\
\hline \multicolumn{4}{|l|}{ Chilodontidae } \\
\hline Caenotropus & & RAG 1/RAG 2/MYH6 & 16 s RNA/ cyt-b \\
\hline Chilodus & & RAG 1/RAG 2/MYH6 & $\begin{array}{l}12 \text { s RNA / D-loop / } \\
16 \text { s RNA/ cyt-b }\end{array}$ \\
\hline \multicolumn{4}{|l|}{ Citharinidae } \\
\hline Citharinus & Osteológicos & $\begin{array}{c}\text { TROP/ fkh/ RAG 2/ Sia/ MYH6/sh3px3/ } \\
\text { ENC1/Gly T/ RAG 1/ RH/ EGR 1/ EGR 2B } \\
\text { EGR3 }\end{array}$ & $\mathrm{COI} /$ cyt-b/nd 2/16 s RNA/ cyt-b \\
\hline \multicolumn{4}{|l|}{ Citharidium } \\
\hline \multicolumn{4}{|l|}{ Citharinops } \\
\hline \multicolumn{4}{|l|}{ Crenuchidae } \\
\hline \multicolumn{4}{|l|}{ Ammocryptocharax } \\
\hline Characidium & $\begin{array}{l}\text { Cariotípicos } \\
\text { Osteológicos }\end{array}$ & $\begin{array}{c}\text { TROP/ fkh/ RAG 2/ Sia/ RAG 1/ MYH6/RH/ } \\
\text { EGR 1/ EGR 2B EGR3 }\end{array}$ & 16 s RNA/ cyt-b \\
\hline Crenuchus & Osteológicos & RAG 1/RAG 2/MYH6 & 16 s RNA/ cyt-b \\
\hline
\end{tabular}

Continua 
continuação

\begin{tabular}{|c|c|c|c|}
\hline GRUPO & \multicolumn{3}{|c|}{ MARCADOR } \\
\hline Elachocharax & & TROP/ fkh/ RAG 2/ Sia & $16 \mathrm{~s}$ RNA/ cyt-b \\
\hline \multicolumn{4}{|l|}{ Geryichthys } \\
\hline \multicolumn{4}{|l|}{ Klausewitzia } \\
\hline \multicolumn{4}{|l|}{ Leptocharacidium } \\
\hline Melanocharacidium & & $\begin{array}{l}\text { TROP/ fkh/ RAG 2/ Sia/ } \\
\text { RAG 1/RAG 2/MYH6 }\end{array}$ & 16 s RNA/ cyt-b \\
\hline \multicolumn{4}{|l|}{ Microcharacidium } \\
\hline \multicolumn{4}{|l|}{ Odontocharacidium } \\
\hline Poecilocharax & & RAG 1/RAG 2/MYH6 & $16 \mathrm{~s}$ RNA/ cyt-b \\
\hline \multicolumn{4}{|l|}{ Skiotocharax } \\
\hline \multicolumn{4}{|l|}{ Ctenoluciidae } \\
\hline Ctenolucius & Osteológicos & $\begin{array}{c}\text { TROP/ fkh/ RAG 2/ Sia/ RAG 1/ MYH6/ RH/ } \\
\text { EGR 1/ EGR 2B EGR3/sh3px3 }\end{array}$ & 16 s RNA/ cyt-b/ COI \\
\hline Boulengerella & Osteológicos & RAG 1/RAG 2/MYH6/ SEPY I/ AEPY 6 & 16 s RNA/ cyt-b \\
\hline \multicolumn{4}{|l|}{ Curimatidae } \\
\hline \multicolumn{4}{|l|}{ Curimata } \\
\hline Curimatella & & RAG 1/RAG 2/MYH6 & 16 s RNA/ cyt-b \\
\hline \multicolumn{4}{|l|}{ Curimatopsis } \\
\hline Cyphocharax & Osteológicos & RAG 1/RAG 2/MYH6 & $\begin{array}{l}12 \text { s RNA / D-loop / } \\
16 \text { s RNA/ cyt-b }\end{array}$ \\
\hline Potamorhina & & RAG 1/RAG 2/MYH6 & 16 s RNA/ cyt-b \\
\hline \multicolumn{4}{|l|}{ Psectogaster } \\
\hline \multicolumn{4}{|l|}{ Pseudocurimata } \\
\hline Steindachnerina & & $\begin{array}{l}\text { RAG 1/RAG 2/MYH6/ } \\
\text { 5S rDNA }\end{array}$ & $\begin{array}{l}12 \text { s RNA / D-loop / } \\
16 \text { s RNA/ cyt-b }\end{array}$ \\
\hline \multicolumn{4}{|l|}{ Cynodontidae } \\
\hline Cynodon & & RAG 1/RAG 2/MYH6 & $16 \mathrm{~s} \mathrm{RNA} /$ cyt-b \\
\hline Gilbertolus & & RAG 1/RAG 2/MYH6 & 16 s RNA/ cyt-b \\
\hline Hydrolycus & & $\begin{array}{l}\text { RAG 1/ RAG 2/MYH6/ RH/ EGR 1/ EGR 2B } \\
\text { EGR3/ TROP/ fkh/ Sia }\end{array}$ & $16 \mathrm{~s}$ RNA/ cyt-b \\
\hline Rhaphiodon & Osteológicos & RAG 1/RAG 2/MYH6/ S7/ TROP/ fkh/ Sia & $\begin{array}{c}12 \text { s RNA / D-loop / } \\
16 \text { s RNA/ cyt-b/ ATPase }\end{array}$ \\
\hline \multicolumn{4}{|l|}{ Distichodontidae } \\
\hline Belonophago & & MYH6/sh3px3/ENC1/Gly T & $\mathrm{COI} / \mathrm{cyt}-\mathrm{b} / \mathrm{nd} 2$ \\
\hline \multicolumn{4}{|l|}{ Congocharax } \\
\hline Distichodus & Osteológicos & $\begin{array}{c}\text { TROP/ fkh/ RAG 2/ Sia/ MYH6/sh3px3/ } \\
\text { ENC1/Gly T/ RAG 1/ RH/ EGR 1/ EGR 2B } \\
\text { EGR3/ SEPY I/ AEPY 6 }\end{array}$ & $\mathrm{COI} / \mathrm{cyt}-\mathrm{b} / \mathrm{nd} 2 / 16 \mathrm{~s}$ RNA \\
\hline \multicolumn{4}{|l|}{ Dundocharax } \\
\hline Eugnathichthys & & MYH6/sh3px3/ENC1/Gly T & $\mathrm{COI} /$ cyt-b/nd 2 \\
\hline Hemigrammocharax & & $\begin{array}{l}\text { TROP/ fkh/ RAG 2/ Sia/ MYH6/sh3px3/ } \\
\text { ENC1/Gly T/ RAG } 1\end{array}$ & COI/cyt-b/nd 2/16 s RNA \\
\hline Hemistichodus & & $\begin{array}{l}\text { TROP/ fkh/ RAG 2/ Sia/ MYH6/sh3px3/ } \\
\text { ENC1/Gly T }\end{array}$ & $\mathrm{COI} / \mathrm{cyt}-\mathrm{b} / \mathrm{nd} 2 / 16 \mathrm{~s}$ RNA \\
\hline Ichthyborus & & $\begin{array}{l}\text { TROP/ fkh/ RAG 2/ Sia/ MYH6/sh3px3/ } \\
\text { ENC1/Gly T/ RAG } 1\end{array}$ & COI/cyt-b/nd 2/16 s RNA \\
\hline Mesoborus & & MYH6/sh3px3/ENC1/Gly T & $\mathrm{COI} / \mathrm{cyt}-\mathrm{b} / \mathrm{nd} 2$ \\
\hline
\end{tabular}


continuação

\begin{tabular}{|c|c|c|c|}
\hline GRUPO & \multicolumn{3}{|c|}{ MARCADOR } \\
\hline Microstomatichthyoborus & & MYH6/sh3px3/ENC1/Gly T & $\mathrm{COI} /$ cyt-b/nd 2 \\
\hline Nannaethiops & & MYH6/sh3px3/ENC1/Gly T & $\mathrm{COI} / \mathrm{cyt}-\mathrm{b} / \mathrm{nd} 2$ \\
\hline Nannocharax & & $\begin{array}{c}\text { TROP/ fkh/ RAG 2/ Sia/ MYH6/sh3px3/ } \\
\text { ENC1/Gly T }\end{array}$ & $\mathrm{COI} / \mathrm{cyt}-\mathrm{b} / \mathrm{nd} 2 / 16 \mathrm{~s}$ RNA \\
\hline Neolebias & & $\begin{array}{c}\text { TROP/ fkh/ RAG 2/ Sia/ MYH6/sh3px3/ } \\
\text { ENC1/Gly T/ RAG } 1\end{array}$ & COI/cyt-b/nd 2/16 s RNA \\
\hline Paradistichodus & & MYH6/sh3px3/ENC1/Gly T & $\mathrm{COI} /$ cyt-b/nd 2 \\
\hline \multicolumn{4}{|l|}{ Paraphago } \\
\hline Phago & & $\begin{array}{c}\text { TROP/ fkh/ RAG 2/ Sia/ MYH6/sh3px3/ } \\
\text { ENC1/Gly T }\end{array}$ & $\mathrm{COI} / \mathrm{cyt}-\mathrm{b} / \mathrm{nd}$ 2/16 s RNA \\
\hline Xenocharax & Osteológicos & $\begin{array}{l}\text { TROP/ fkh/ RAG 2/ Sia/ MYH6/sh3px3/ } \\
\text { ENC1/Gly T/ RAG } 1\end{array}$ & COI/cyt-b/nd 2/16 s RNA \\
\hline \multicolumn{4}{|l|}{ Erythrinidae } \\
\hline Erythrinus & & RAG 1/RAG 2/MYH6 & 16 s RNA/ cyt-b \\
\hline Hoplerythrinus & Osteológicos & RAG 1/RAG 2/MYH6 & 16 s RNA/ cyt-b \\
\hline Hoplias & Osteológicos & $\begin{array}{c}\text { TROP/ fkh/ RAG 2/ Sia/ } \\
\text { RAG 1/ RH/ EGR 1/ EGR 2B EGR3/ MYH6/ } \\
\text { sh3px3/ SEPY I/ AEPY 6 }\end{array}$ & 16 s RNA/ cyt-b/ COI \\
\hline \multicolumn{4}{|l|}{ Gasteropelecidae } \\
\hline Carnegiella & Osteológicos & RAG 1/RAG 2/MYH6 & $\begin{array}{l}12 \text { s RNA / } 16 \text { s RNA/ } \\
\text { cyt-b/ COI }\end{array}$ \\
\hline Clupeacharax & & RAG 1/RAG 2/MYH6 & 16 s RNA/ cyt-b \\
\hline Gasteropelecus & & RAG 1/RAG 2/MYH6/ SEPY I/ AEPY 6 & $\begin{array}{c}12 \text { s RNA/16 s RNA/ } \\
\text { cyt-b/ COI }\end{array}$ \\
\hline Thoracocharax & Osteológicos & RAG 1/RAG 2/MYH6 & $\begin{array}{c}12 \mathrm{~s} \text { RNA / } 16 \mathrm{~s} \text { RNA/ cyt-b/ } \\
\text { COI }\end{array}$ \\
\hline \multicolumn{4}{|l|}{ Hemiodontidae } \\
\hline Anodus & & RAG 1/RAG 2/MYH6 & 16 s RNA/ cyt-b \\
\hline Argonectes & & RAG 1/RAG 2/MYH6 & 16 s RNA/ cyt-b \\
\hline Bivibranchia & & RAG 1/RAG 2/MYH6 & 16 s RNA/ cyt-b \\
\hline Hemiodus & Osteológicos & RAG 1/RAG 2/MYH6/ SEPY I/ AEPY 6 & $\begin{array}{l}12 \text { s RNA / D-loop / } \\
16 \text { s RNA/ cyt-b }\end{array}$ \\
\hline \multicolumn{4}{|l|}{ Micromischodus } \\
\hline \multicolumn{4}{|l|}{ Hepsetidae } \\
\hline Hepsetus & Osteológicos & $\begin{array}{c}\text { TROP/ fkh/ RAG 2/ Sia/ RAG 1/ RH/ EGR 1/ } \\
\text { EGR 2B EGR3/ MYH6 }\end{array}$ & 16 s RNA/ cyt-b \\
\hline \multicolumn{4}{|l|}{ Iguanodectidae } \\
\hline Bryconops & $\begin{array}{l}\text { Espermáticos } \\
\text { Osteológicos }\end{array}$ & $\begin{array}{c}\text { TROP/ fkh/ RAG 2/ Sia/ } \\
\text { RAG 1/MYH6 }\end{array}$ & $\begin{array}{l}12 \text { s RNA/16 s RNA/ } \\
\text { cyt-b/ COI/ND2 }\end{array}$ \\
\hline Iguanodectes & Osteológicos & RAG 1/RAG 2/MYH6 & 16 s RNA/ cyt-b \\
\hline Piabucus & Osteológicos & RAG 1/RAG 2/MYH6 & 16 s RNA/ cyt-b \\
\hline \multicolumn{4}{|l|}{ Lebiasinidae } \\
\hline Nannostomus & & $\begin{array}{c}\text { TROP/ fkh/ RAG 2/ Sia/ RAG 1/ RH/ EGR 1/ } \\
\text { EGR 2B EGR3 }\end{array}$ & 16 s RNA/ cyt-b \\
\hline \multicolumn{4}{|l|}{ Copeina } \\
\hline Copella & & RAG 1/RAG 2/MYH6 & 16 s RNA/ cyt-b \\
\hline \multicolumn{4}{|l|}{ Derhamia } \\
\hline Pyrrhulina & Osteológicos & RAG 1/RAG 2/MYH6 & $16 \mathrm{~s}$ RNA/ cyt-b \\
\hline
\end{tabular}


conclusão

\begin{tabular}{|c|c|c|c|}
\hline GRUPO & \multicolumn{3}{|c|}{ MARCADOR } \\
\hline \multicolumn{4}{|l|}{ Lebiasina } \\
\hline \multicolumn{4}{|l|}{ Parodontidae } \\
\hline Apareiodon & $\begin{array}{l}\text { Osteológicos } \\
\text { Cariotípicos }\end{array}$ & RAG 1/RAG 2/MYH6 & $\begin{array}{l}12 \text { s RNA / D-loop/ } \\
16 \text { s RNA/ cyt-b }\end{array}$ \\
\hline Parodon & Osteológicos & RAG 1/RAG 2/MYH6 & 16 s RNA/ cyt-b \\
\hline \multicolumn{4}{|l|}{ Saccodon } \\
\hline \multicolumn{4}{|l|}{ Prochilodontidae } \\
\hline \multicolumn{4}{|l|}{ Ichthyoelephas } \\
\hline Prochilodus & Osteológicos & RAG 1/RAG 2/MYH6 & $\begin{array}{c}\text { ATPase 6/ ATPase 8/ } \\
12 \text { s RNA / D-loop / } \\
16 \text { s RNA/ cyt-b }\end{array}$ \\
\hline Semaprochilodus & & $\begin{array}{c}\text { RAG 1/ RH/ EGR 1/ EGR 2B EGR3/ RAG 2/ } \\
\text { MYH6 }\end{array}$ & $\begin{array}{l}\text { ATPase 6/ ATPase 8/ } \\
16 \text { s RNA/ cyt-b }\end{array}$ \\
\hline \multicolumn{4}{|l|}{ Serrasalmidae } \\
\hline Acnodon & & & $\begin{array}{l}12 \text { s RNA /16 s RNA/ } \\
\text { D-loop }\end{array}$ \\
\hline Catoprion & Osteológicos & RAG 1/RAG 2/MYH6 & $\begin{array}{l}12 \text { s RNA / D-loop/ } \\
16 \text { s RNA/ cyt-b }\end{array}$ \\
\hline Colossoma & & $\begin{array}{c}\text { TROP/ fkh/ RAG 2/ Sia/ } \\
\text { RAG 1//MYH6 }\end{array}$ & $\begin{array}{l}12 \text { s RNA/D-loop / } \\
16 \text { s RNA/ cyt-b }\end{array}$ \\
\hline Metynnis & $\begin{array}{l}\text { Espermáticos } \\
\text { Osteológicos }\end{array}$ & $\begin{array}{l}\text { TROP/ fkh/ RAG 2/ Sia/RAG 1/ MYH6/ } \\
\text { SEPY I/ AEPY } 6\end{array}$ & $\begin{array}{c}12 \text { s RNA / D-loop/ } \\
16 \text { s RNA/ cyt-b }\end{array}$ \\
\hline Mylesinus & & TROP/ fkh/ RAG 2/ Sia & $\begin{array}{c}12 \text { s RNA / } 16 \text { s RNA/ COI/ D- } \\
\text { loop/ cyt-b }\end{array}$ \\
\hline \multicolumn{4}{|l|}{ Myletes } \\
\hline Myleus & & TROP/ fkh/ RAG 2/ Sia & $\begin{array}{l}12 \text { s RNA /16 s RNA/ } \\
\text { D-loop/ cyt-b }\end{array}$ \\
\hline Myloplus & & RAG 1/RAG 2/MYH6 & $\begin{array}{l}12 \text { s RNA / D-loop / } \\
16 \text { s RNA/ cyt-b }\end{array}$ \\
\hline Mylossoma & Espermáticos & $\begin{array}{c}\text { TROP/ fkh/ RAG 2/ Sia/ } \\
\text { RAG 1/ MYH6 }\end{array}$ & $\begin{array}{l}12 \text { s RNA / D-loop / } \\
16 \text { s RNA/ cyt-b }\end{array}$ \\
\hline Ossubtus & & & $\begin{array}{l}12 \text { s RNA /16 s RNA/ } \\
\text { D-loop }\end{array}$ \\
\hline Piaractus & $\begin{array}{l}\text { Espermáticos } \\
\text { Osteológicos }\end{array}$ & $\begin{array}{c}\text { TROP/ fkh/ RAG 2/ Sia/ } \\
\text { RAG 1/ MYH6 }\end{array}$ & $\begin{array}{l}12 \text { s RNA /16 s RNA/ } \\
\text { cyt-b/ COI/ D-loop }\end{array}$ \\
\hline Pristobrycon & & & $\begin{array}{l}12 \text { s RNA/16 s RNA/ } \\
\text { D-loop }\end{array}$ \\
\hline Pygocentrus & & $\begin{array}{c}\text { TROP/ fkh/ RAG 2/ Sia/ } \\
\text { RAG 1/ MYH6 }\end{array}$ & $\begin{array}{l}12 \text { s RNA/16 s RNA/ } \\
\text { cyt-b/ COI/ D-loop }\end{array}$ \\
\hline Pygopristis & & & $\begin{array}{l}12 \text { s RNA /16 s RNA/ } \\
\text { D-loop }\end{array}$ \\
\hline Serrasalmus & $\begin{array}{l}\text { Espermáticos } \\
\text { Osteológicos } \\
\end{array}$ & $\begin{array}{c}\text { TROP/ fkh/ RAG 2/ Sia/ } \\
\text { RAG 1/ MYH6 }\end{array}$ & $\begin{array}{l}12 \text { s RNA /16 s RNA/ } \\
\text { cyt-b/ D-loop }\end{array}$ \\
\hline Tometes & & RAG 1/RAG 2/MYH6 & $\begin{array}{l}12 \text { s RNA / D-loop / } \\
16 \text { s RNA/ cyt-b }\end{array}$ \\
\hline \multicolumn{4}{|l|}{ Utiaritichthys } \\
\hline \multicolumn{4}{|l|}{ Triportheidae } \\
\hline Agoniates & Osteológicos & RAG 1/RAG 2/MYH6 & 16 s RNA/ cyt-b \\
\hline Clupeacharax & & RAG 1/RAG 2/MYH6 & 16 s RNA/ cyt-b \\
\hline Engraulisoma & Osteológicos & RAG 1/RAG 2/MYH6 & 16 s RNA/ cyt-b \\
\hline Lignobrycon & Osteológicos & RAG 1/RAG 2/MYH6 & 16 s RNA/ cyt-b \\
\hline Triportheus & Osteológicos & $\begin{array}{l}\text { TROP/ fkh/ RAG 2/ Sia/ } \\
\text { RAG 1/ MYH6 }\end{array}$ & $\begin{array}{l}12 \mathrm{~s} \mathrm{RNA} / 16 \mathrm{~s} \text { RNA/ } \\
\text { cyt-b/ COI }\end{array}$ \\
\hline
\end{tabular}


Entre as abordagens utilizadas em filogenética, o papel das evidências morfológicas e moleculares na reconstrução da filogenia tem passado por rigorosas avaliações (HILLIS, 1987; SCOTLAND et al., 2003; SMITH; TURNER, 2005; DE CARVALHO et al., 2008). Entre os marcadores utilizados para as análises filogenéticas nos artigos encontrados, a grande maioria utilizou caracteres moleculares (Figura 3).

Figura 3- Marcadores utilizados nas análises filogenéticas dos Characiformes

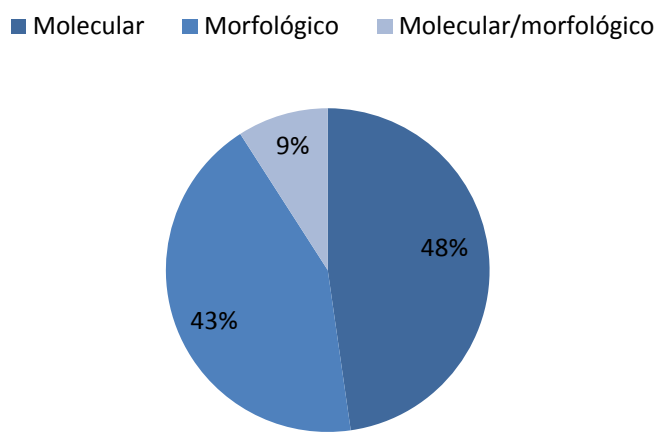

Nos estudos que utilizaram marcadores moleculares, $48 \%$ foram realizados utilizando marcadores nucleares e mitocondriais. Somente marcadores mitocondriais foram utilizados em $40 \%$ dos artigos, e apenas 12\% dos trabalhos usaram unicamente marcadores nucleares. Os marcadores mitocondriais são mais utilizados em filogenias. $\mathrm{O}$ DNA mitocondrial possui algumas características favoráveis, como ausência de recombinação, herança materna, alta taxa de mutação e fácil isolamento; desta forma, até mesmo espécies muito próximas podem ser discriminadas (RUBINOFF, 2006).

Entre os marcadores mitocondriais mais utilizados estão sequências parciais de genes $16 \mathrm{~s} r R N A$,cyt- $b$ e coi. A maior parte dos trabalhos com genes nucleares utilizou myh6, rag1 e rag2. As análises morfométricas foram as mais usadas como marcadores morfológicos, seguidas de caracteres osteológicos e cariótipo.

De acordo com os defensores da filogenética morfológica, somente a morfologia pode estabelecer relações entre táxons vivos e fósseis (WIENS, 2004), em reconstrução de clados com divergência profunda e radiação rápida, as análises moleculares podem não ser tão confiáveis (ROKAS et al., 2003). Por outro lado, o sequenciamento do DNA possui vários benefícios como: grande quantidade de dados de forma rápida e barata, as sequências parecem oferecer uma medida mais objetiva, além de não sofrerem interferência ambiental (WHEELER et al., 2013). Contudo vários autores defendem que o DNA é mais uma entre várias fontes de evidências, e que todas as evidências disponíveis devem ser usadas para reconstruir a filogenia, tanto molecular como morfológica (WIENS, 2004; SMITH; TURNER, 2005; WHEELER et al., 2013).

Vários trabalhos estão sendo realizados envolvendo análises combinadas, demonstrando que em alguns casos somente as análises simultâneas podem resultar em filogenias bem resolvidas (CARPENTER, 1999; FREITAS; BROWN, 2004; WAHLBERG et al., 2005). Como exemplo, para estabelecer a filogenia da família Alestidae, Hubert et al. (2005) utilizaram dados morfológicos e moleculares em análise combinada. Neste estudo, ambos os dados foram complementares. No entanto, nos artigos encontrados somente $9 \%$ utilizaram análises combinadas para estabelecer a filogenias de Characiformes. As parcerias realizadas pode ser um dos fatores para explicar os poucos trabalhos que utilizaram dados de diferentes abordagens em suas análises, pois nesses artigos a média de autores foi de três e esses estavam filiados a departamentos diferentes.

$\mathrm{O}$ número médio de autores por trabalho foi de 3,73 , e o artigo com maior quantidade de autores foi Chromosomalpainting and $Z W$ sex chromosomes differentiation in Characidium (Characiformes, Crenuchidae), com onze autores no total. Dois trabalhos tiveram autoria de só um autor.

Considerando o número de total de artigos e o país em que os autores estão filiados, $43,1 \%$ dos trabalhos foram realizados por instituições brasileiras, 11,3 \% por instituições americanas (Figura 4). Muitos trabalhos foram realizados em parcerias entre diferentes países, num total de $31,8 \%$. Destes, três foram realizados por autores de três países diferentes e onze em parceria entre dois países. Cinco trabalhos foram feitos em parceria entre Brasil e Estados Unidos (Figura 5). 
Figura 4- Número de artigos sobre filogenia de Characiformes em relação ao país de filiação dos autores

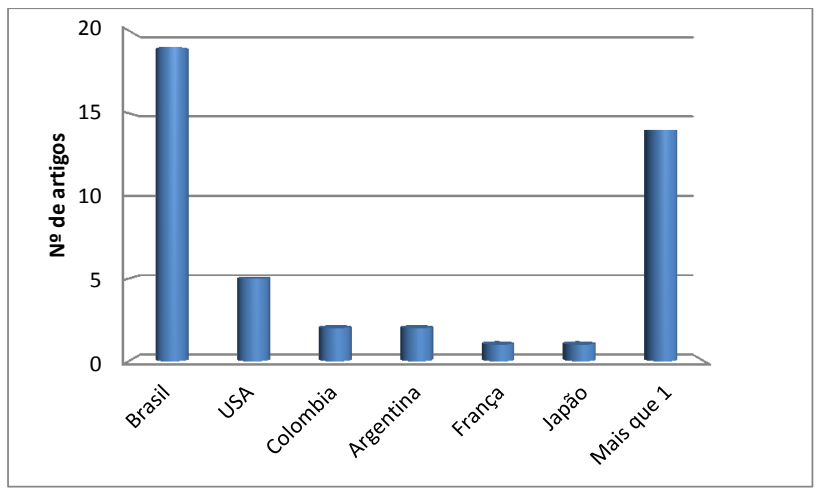

Figura 5- Países que realizaram parcerias nos trabalhos sobre filogenia dos Characiformes

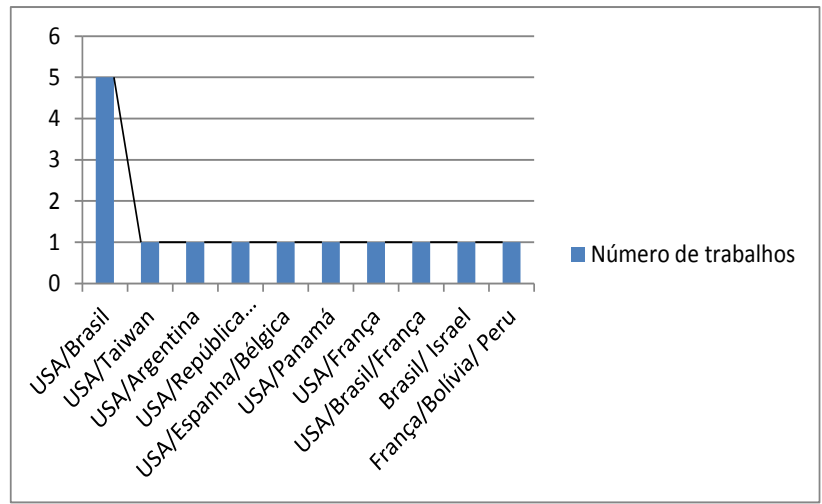

O Brasil possui um número expressivo em publicações; uma das razões é que o país lidera o número de peixes de água doce, com mais de 2.500 espécies catalogadas (BUCKUP et al., 2007). Os Estados Unidos ficaram com a segunda posição, e são o país que mais realizou parcerias. O maior número de publicações de autores americanos reflete o investimento local em infraestrutura e pesquisa (JAPPE, 2007). As vantagens das colaborações científicas dependem do tipo de pesquisa, da disciplina, das instituições e dos países envolvidos. A colaboração internacional, além de aumentar o número de citações, também favorece pequenas universidades e países em desenvolvimento (GOLDFINCH et al., 2003).

O impacto de um artigo, medido pelo número de citações, expressa a importância e reconhecimento de uma obra em seu meio (MACIAS-CHAPULA,
1998). Neste sentido, o trabalho mais citado foi "Patterns of nucleotide change in mitochondrial ribosomal RNA genes and the phylogeny of piranhas", com 123 citações (Tabela 2). Por outro lado, 61,3 $\%$ dos artigos foram citados menos de dez vezes. Esta é uma tendência esperada na literatura, em que poucos artigos são muitos citados, enquanto muitos recebem pouca ou nenhuma citação (NICOLAISEN; HJORLAND, 2007). O número de citações depende do ano de publicação (YU; LI, 2007). Portanto, artigos antigos tendem a ser mais citados que os mais recentes, fato corroborado pelos nossos resultados. É possível verificar também que os trabalhos que apresentam uma abordagem mais ampla também são mais citados.

Tabela 2- Artigos selecionados sobre análise filogenética de Characiformes que foram mais citados

\begin{tabular}{c|c|c|c}
\hline Citações & Artigo & Autor & Ano \\
\hline 123 & $\begin{array}{c}\text { Patterns of nucleotide change in } \\
\text { mitochondrial ribosomal RNA } \\
\text { genes and the phylogeny of } \\
\text { piranhas }\end{array}$ & Guillermo Ortiet al. & 1996 \\
\hline 112 & $\begin{array}{c}\text { Mitochondrial genomics } \\
\text { of ostariophysan fishes: } \\
\text { Perspectives on phylogeny and } \\
\text { biogeography }\end{array}$ & Kenji Saitoh et al. & 2003 \\
\hline 84 & $\begin{array}{c}\text { Population structure and } \\
\text { biogeography of migratory } \\
\text { freshwater fishes (Prochilodus : } \\
\text { Characiformes) in major South } \\
\text { American rivers }\end{array}$ & Arjun Sivasundar \\
et al. & 2001 \\
\hline & $\begin{array}{c}\text { Relationships among } \\
\text { characiform fishes inferred } \\
\text { from analysis of nuclear and } \\
\text { mitochondrial gene sequences }\end{array}$ & $\begin{array}{c}\text { Daniela Calcagnotto } \\
\text { et al. }\end{array}$ & 2005 \\
\hline
\end{tabular}

Geralmente, a revista em que o artigo foi publicado é um dos critérios utilizados para avaliar a área de conhecimento da pesquisa (VANTI, 2002). Ao todo, 24 periódicos publicaram sobre o assunto, e as revistas que mais publicaram foram Molecular Phylogenetics and Evolution e Neotropical Ichthyology, ambas com oito trabalhos. A primeira é específica em trabalhos relacionados com filogenia molecular, e a segunda aborda estudos sobre peixes neotropicais. Entre as revistas específicas que publicaram sobre o tema estão as da área de genética, zoologia, evolução e molecular. Poucos trabalhos foram publicados em revistas mais generalistas. 


\section{CONCLUSÕES}

Conhecer melhor os padrões de diversidade é essencial para informar aos conservacionistas quais esforços devem ser priorizados. Como a ordem Characiformes é um dos mais importantes componentes de águas doces neotropicais, entender a história evolutiva do grupo e suas implicações para a taxonomia é extremamente necessário.

Desta forma, todos os meios que identifiquem o estado atual de conhecimento do grupo auxiliam a delimitar quais lacunas precisam ser preenchidas. Por meio deste trabalho, podemos concluir que a filogenia de Characiformes ainda não está bem resolvida.Apenas alguns táxons foram estudados e poucos trabalhos fizeram uma análise mais abrangente da ordem. A filogenia de algumas famílias ainda não foi bem investigada. Entre os gêneros da ordem, setenta ainda não foram estudados em análises filogenéticas, vários destes são considerados incertae sedis. A maioria das filogenias utilizou abordagem molecular e o Brasil é o país que mais contribuiu com estudos neste assunto, tendo revistas com diferentes enfoques.

Portanto, sugerimos que novas pesquisas sejam feitas para melhorar o conhecimento da filogenia de Characiformes, sobretudo análises mais abrangentes, em nível de ordem, e entre os grupos pouco estudados. Análises com dados moleculares e morfológicos também podem auxiliar nesta problemática.

\section{REFERÊNCIAS}

AMORIM, D. S. Fundamentos de sistemática filogenética. Ribeirão Preto: Holos, 2002.

BRUFREM, L., PRATES, Y. O saber científico registrado e as práticas de mensuração da informação. Ciência da Informação, Brasília, v. 34, n. 2, p.9-25, 2005.

BUCKUP, P. A., N. A. MENEZES, N. A; GHAZZI, M. S. Catálogo das espécies de peixes de água doce do Brasil. Rio de Janeiro, Museu Nacional, 195p, 2007.

CAlCAGNOTTO, D.; SCHAEFER, S. A.; DESALlE, R. Relationships among characiform fishes inferred from analysis of nuclear and mitochondrial gene sequences. Molecular Phylogenetics and Evolution, v. 36, n. 1, p.135-153, 2005.

CARPENTER, J. M. Towards simultaneous analysis of morphological and molecular data in Hymenoptera. ZoologicaScripta, v. 28, n. 1-2, p.251-260, 1999.

COSTEllo, M. J.; MAY, R. M.; STORK, N. E. Can we name Earth's species before they go extinct?. Science, v. 339, n. 6118, p.413-416, 2013.
DATOVO, A.; CASTRO, R. Anatomy and evolution of the mandibular, hyopalatine, and opercular muscles in characiform fishes (Teleostei: Ostariophysi). Zoology, v.115, n. 2, p.84-116, 2012.

DE CARVALHO, M. R. et al. Systematics must embrace comparative biology and evolution, not speed and automation. Evolutionary Biology, v. 35, n. 2, p. 150-157, 2008.

ESCHMEYER, W. N.; FONG, J. D. Species by Family/ Subfamily. Disponível em: <http://research.calacademy. org/research/ichthyology/catalog/SpeciesByFamily.asp $>$ Acesso em: 19 dez. 2013.

FREITAS, A.; BROWN, K. S. Phylogeny of the Nymphalidae (Lepidoptera). Systematic Biology, v.53, n.3, p.363-383, 2004.

GÉRY, J. Characoids of the world. New Jersey, Nepture City: T. F. H. Publications, 1977.

GOLDFINCH, S.; DALE, T.; DEROUEN, K. Science from the periphery: collaboration, networks and' Periphery Effects' in the citation of New Zealand Crown Research Institutes articles, 1995-2000. Scientometrics, v.57, n.3, p.321-337, 2003.

HENNIG, W. Phylogenetic systematics. Urbana: University of Illinois Press, 1999.

HILLIS, D. M. Molecular versus morphological approaches to systematics. Annual Review of Ecology and Systematics, v.18, p.23-42, 1987.

HUBERT, N.; BONILlO, C.; PAUGY, D. Early divergence among the Alestidae (Teleostei, Ostariophyses, Characiformes): mitochondrial evidences and congruence with morphological data. Comptes Rendus Biologies, v.328, n.5, p.477-491, 2005.

JAVONILLO, R. et al. Relationships among major lineages of characid fishes (Teleostei: Ostariophysi: Characiformes), based on molecular sequence data. Molecular Phylogenetics and Evolution, v.54, n.2, p.498, 2010.

JAPPE, A. Explaining international collaboration in global environmentalchange research. Scientometrics, v.71, n.3, p.367-390, 2007.

LAURINDO, R.; MAFRA, T. Cienciometria da revista Comunicação \& Sociedade identifica interfaces da área. Comunicação \& Sociedade, n.53, p. 233-260, jan./jun. 2010.

LIMA, F. C. T., et al. Check List of the Freshwater Fishes of South and Central America. Porto Alegre: Edipucrs, 2003. p.106-169.

LOWE-MCCONNELL, R. Estudos ecológicos em comunidades de peixes tropicais. São Paulo: EDUSP, 1999.

MACIAS-CHAPULA, C. A. O papel da informetria e da cienciometria sua perspectivanacional einternacional. Ciência da informação, v.27, n.2, p.134-140, 1998. 
MATTOX, G. M. T; TOLEDO-PIZA, M. Phylogenetic study of the Characinae (Teleostei: Characiformes: Characidae). Zoological Journal of the Linnean Society, v.165, n.4, p.809-915, 2012.

MIRANDE, J. M. Phylogeny of the family Characidae (Teleostei: Characiformes): from characters to taxonomy. Neotropical Ichthyology, v.8, n.3, p. 385-568, 2010.

NELSON, J. S. Fishes of the world. New York: John Wiley \& Sons, 2006.

NICOLAISEN, J.; HJORLAND, B. Practical potentials of Bradford's law: a critical examination of the received view. Journal of Documentation, v.63, n.3, p.359-377, 2007.

OLIVEIRA, C. et al. Phylogenetic relationships within the speciose family Characidae (Teleostei: Ostariophysi: Characiformes) based on multilocus analysis and extensive ingroup sampling. BMC Evolutionary Biology, v.11, n.1, p.275, 2011.

ORTÍ, G. et al. Patterns of nucleotide change in mitochondrial ribosomal RNA genes and the phylogeny of piranhas. Journal of Molecular Evolution, v.42, n.2, p.169-182, 1996.

ROKAS, A. et al. Conflicting phylogenetic signals at the base of the metazoan tree. Evolution \& Development, v.5, n.4, p.346-359, 2003.

RUBINOFF, D. Utility of mithochondrial DNA barcodes in species conservation. Conservation Biology, v.20, n.4, p.1026-1033, 2006.

SAITOH, K. et al. Mitochondrial genomics of ostariophysan fishes: perspectives on phylogeny and biogeography. Journal of Molecular Evolution, v.56, n.4, p.464-472, 2003.

SCOTLAND, R. W.; OLMSTEAD, R. G.; BENNETT, J. R. Phylogeny reconstruction: the role of morphology. Systematic Biology, v.52, n.4, p.539-548, 2003.

SIVASUNDAR, A. et al. Population structure and biogeography of migratory freshwater fishes (Prochilodus: Characiformes) in major South American rivers. Molecular Ecology, v.10, n.2, p.407-417, 2001.

SPINAK, E. Indicadores cienciométricos. Ciência da Informação, v.27, n.2, p. 141- 148, 1998.

SMITH,N.D.;TURNER,A.H. Morphology's rolein phylogeny reconstruction: perspectives from paleontology. Systematic Biology, v.54, n.1, p.166-173, 2005.

TAGUE-SUTCLIFFE, J. An introduction to informetrics. Information processing \& management, v.28, n.1, p.1- 3, 1992.

VANTI, N. A. P. Da bibliometria à webometria: uma exploração conceitual dos mecanismos utilizados para medir o registro da informação e a difusão do conhecimento. Ciência da Informação, v.31, n.2, p.152-162, 2002.
WAHLBERG, N. et al. Synergistic effects of combining morphological and molecular data in resolving the phylogeny of butterflies and skippers. Proceedings of the Royal Society B: Biological Sciences, v.272, n.1572, p.1577-1586, 2005.

WEITZMAN, S. H.; PALMER, L. Family Gasteropelecidae (Freshwater hatchetfishes). In: REIS, R. E.; KULLANDER, S. O.; FERRARIS, C. J. Check List of the Freshwater Fishes of South and Central America (CLOFFSCA). Porto Alegre: Edipucrs, 2003. p. 101-103.

WHEELER, Q.; ASSIS, L.; RIEPPEL, O. Phylogenetics: heed the father of cladistics. Nature, v.496, n.7445, p.295-296, 2013.

WHEELER, W. et al. Dynamic homology and phylogenetic systematics: a unified approach using POY. New York: American Museum of Natural History, 2006.

WIENS, J. J. The role of morphological data in phylogeny reconstruction. Systematic Biology, v.53, n.4, p.653-661, 2004.

YU, G.; LI, Y. Parameter identification of the observed citation distribution. Scientometrics, v.71, n.2, p.339- 348, 2007. 